\title{
PENGARUH MODAL PSIKOLOGIS, KOMITMEN ORGANISASI DAN IKLIM PSIKOLOGIS TERHADAP KESIAPAN DALAM MENGHADAPI PERUBAHAN
}

\author{
Desy Widiarti \\ Desy.widiarti@gmail.com \\ HIMPSI DKI Jakarta
}

\author{
Akhmad Baidun \\ akhmad.baidun@uinjkt.ac.id \\ UIN Syarif Hidayatullah \\ Jakarta
}

\begin{abstract}
This study aims to examine effects of psychological capital, organizational commitment, and psychological climate on readiness to face changes. 162 employees were picked u 7 sing accidental sampling technique. Modified version of Holt, Armenakis, Field, and Haris' Measuring Readiness for Change (2007), Psychological Capital Questionnaire (PCQ) developed by Luthans, Youssef, and Avolio (2007), measuring organizational commitment developed by Allen and Mayer (1990), and Psychological Climate Scale developed by Brown and Leigh (1996). Instruments validity testings were done using Confirmatory Factor Analysis. Hypothesis testing was done using multiple regression analysis. Result of this study showed that there are significant effects if psychological capital, organizational commitment, and psychological climate on readiness to face changes. Authors hope implication of this study can be studied further and developed in the next studies.
\end{abstract}

Keyword : Psychological capital, organizational commitment, psychological climate, readiness to face changes

\begin{abstract}
Abstrak
Penelitian ini bertujuan untuk mengetahui pengaruh modal psikologis, komitmen organisasi, dan iklim psikologis terhadap kesiapan dalam menghadapi perubahan. Sampel berjumlah 162 orang yang diambil dengan teknik accidental sampling. Penulis memodifikasi Measuring Readiness for Change yang dibuat oleh Holt, Armenakis, Field, dan Haris (2007), modal psikologis questionare (PCQ) yang dibuat oleh Luthans, Youssef, dan Avolio (2007), measuring komitmen organisasi yang dibuat oleh Allen dan Mayer (1990), dan iklim psikologis scale yang dibuat oleh Brown dan Leigh (1996). Uji validitas alat ukur menggunakan teknik confirmatory factor analysis (CFA). Uji hipotesis penelitian menggunakan teknik analisis regresi berganda. Hasil penelitian menunjukkan bahwa ada pengaruh yang signifikan modal psikologis, komitmen organisasi, dan iklim psikologis terhadap kesiapan dalam menghadapi perubahan. Penulis berharap implikasi dari penelitian ini dapat dikaji kembali dan dikembangkan pada penelitian selanjutnya.
\end{abstract}

Kata kunci: Modal psikologis, komitmen organisasi, iklim psikologis, kesipan dalam menghadapi perubahan. 
Kondisi persaingan bisnis yang sangat dinamis dan kompleks memaksa setiap entitas bisnis harus terus berubah atau melakukan inovasi agar tetap bisa bertahan. Salah satu strategi untuk menyikapi lingkungan bisnis yang dinamis dan kompleks yaitu dengan cara melakukan perubahan atau perbaikan secara terus- menerus (continuous improvement). Perubahan merupakan elemen yang penting dalam setiap bisnis. Berdasarkan changes management survey report dalam Survey of Human Resources Management (SHRM) 2007, sebanyak 82 persen human resource professional mengatakan bahwa perusahaan mempunyai rencana untuk mengimplementasikan perubahan perusahaan yang bersifat umum untuk jangka waktu dua tahun ke depan (Majalah Human Capital, edisi 47 Febuari 2008). Hasil survey yang telah dilakukan oleh SHRM memperlihatkan bahwa sebagian besar perusahaan sadar arti penting melakukan perubahan.

Begitu banyak perusahaan yang melakukan perubahan atau change management ketika memasuki keadaan yang sangat parah atau kronis dan membutuhkan usaha yang besar serta biaya yang besar juga untuk memulihkan perusahaan dengan kondisi kronis tersebut. Freek, Phanis, Ranjay (2010) menyatakan bahwa perusahaan yang kelihatannya sehat atau tidak memiliki masalah atau bahkan dalam kondisi puncak juga perlu melakukan sebuah perubahan dikarenakan kondisi persaingan dan dunia bisnis yang dinamis dan kompleks. Oleh karena itu untuk menyikapi dan memenangkan persaingan yang semakin ketat setiap perusahaan sangat perlu memperhatikan kesehatan perusahaan.

Perusahaan yang tidak dapat bertahan karena tidak dapat mengikuti perubahan zaman salah satunya adalah toko musik yang menjual cd atau kaset Disc Tarra. Disc Tarra tutup pada bulan 31 Desember 2015 serentak di seluruh Indonesia. Menurut pengamat musik Bens Leo mengatakan bahwa tren fisik secara album sekarang sudah berkurang, sehingga banyak perusahaan yang enggan bisa bertahan, hal ini juga terjadi pada Aquarius tahun 2013 silam.

Pada dasarnya perubahan akan menimbulkan sebuah penolakan atau resistensi dimana berdasarkan penelitian terdahulu menyatakan bahwa perubahan bukanlah suatu hal yang mudah untuk dilakukan, entah itu perubahan sistem, proses perubahan, atau perubahan struktural. Gagasan bahwa perubahan menyebabkan penolakan bukanlah hal baru. Perubahan mempengaruhi bisnis dan karyawan dalam berbagai cara. Setiap orang bereaksi berbeda terhadap perubahan dan perubahan tersebut dapat disambut dengan baik oleh beberapa orang, tetapi untuk orang lain yang tidak menginginkan perubahan biasanya mereka akan menolak (Bovey \& Hede, 2001).

Penolakan karyawan terhadap perubahan dilakukan karena ketidaksiapan karyawan terhadap hasil dari perubahan organisasi. Perubahan yang dilakukan oleh perusahaan ada yang kurang berhasil, bahkan perubahan yang dilakukan dapat menambah masalah baru, seperti distress pada karyawan yang 
mengakibatkan karyawan kurang puas dan sering absen kerja. Karyawan yang mengalami distress disebabkan karena keryawan kurang siap dalam menerima perubahan organisasi (Yuwono \& Putra, 2005).

Kesiapan dalam menghadapi perubahan merupakan hal penting yang harus diperhatikan ketika perusahaan ingin melakukan perubahan. Madsen, Miller, dan John (2005) menyatakan bahwa kesiapan dalam menghadapi perubahan (readiness for organizational change) merupakan sekumpulan pemikiran dan keinginan individu untuk menghadapi perubahan tertentu di dalam organisasi. Kesiapan tersebut meliputi: keyakinan sikap dan intensi individu untuk menghadapi individu yang meyakini bahwa organisasi harus melakukan serangkaian perubahan demi keberlangsungan dan kemajuan organisasi, individu tersebut juga bersifat positif terhadap perubahan yang dilakukan organisasi (Madsen, Miller, \& John, 2005).

Terdapat faktor internal dan eksternal yang berhubungan dengan kesiapan dalam menghadapi perubahan (individual readiness for organizational change). Adapun faktor internal yang berasal dari dalam diri individu yaitu modal psikologis (Avey, Wernsing, \& Luthans, 2008). Sedangkan faktor eksternal yang berasal dari luar diri individu, antara lain: komitmen organisasi (Medsen, Miller, \& John, 2005), iklim psikologis (Martin, Jones, \& Callan, 2005).

Faktor internal yang mempengaruhi kesiapan dalam menghadapi perubahan yaitu modal psikologis. Luthans, Youssef, dan Avolio (2007) menyatakan bahwa modal psikologis merupakan kapasitas positif psikologis yang dimiliki oleh setiap individu yang berguna dalam membantu individu tersebut untuk dapat berkembang yang ditandai oleh: (1) percaya diri (self efficacy) untuk menyelesaikan pekerjaan; (2) memiliki pengharapan positif (optimism) tentang keberhasilan saat ini dan dimasa yang akan datang; (3) tekun dalam berharap (hope) untuk berhasil; dan (4) ketahanan dalam menghadapi berbagai permasalahan (resiliency) hingga mencapai sukses.

Modal psikologis berpengaruh terhadap kesiapan dalam menghadapi perubahan. Menurut Avey, Wersing dan Luthans (2008) bahwa modal psikologis mempengaruhi perubahan organisasi karena untuk melakukan perubahan organisasi dibutuhkan sumber daya manusia yang memiliki harapan yang kuat terhadap perubahan, percaya diri, yakin akan kemampuannya dalam menghadapi perubahan, dan tahan pada kondisi yang sulit. Hal tersebut tercangkup dalam dimensi yang terdapat pada modal psikologis.

Faktor eksternal yang mempengaruhi kesiapan dalam menghadapi perubahan yaitu komitmen organisasi. Madsen, Miller, dan John (2005) menyatakan bahwa individu yang memiliki komitmen organisasi tinggi akan cenderung mendukung perubahan yang dilakukan oleh organisasinya. Menurut Allen dan Mayer (1990), komitmen organisasi merupakan suatu kelekatan psikologis antara seorang karyawan dan organisasinya. Jika individu kurang 
memiliki komitmen organisasi, maka karyawan akan dengan mudah meninggalkan organisasinya.

Berdasarkan penelitian yang dilakukan oleh Allen dan Mayer (1990) komitmen organisasi terdiri dari tiga komponen, yakni affective commitment, continuance commitment, dan normative commitment. Affective commitment merupakan komitmen yang bersumber dari emosional karyawan, identifikasi karyawan, dan keterlibatan karyawan terhadap organisasinya, sehingga karyawan sangat ingin untuk tetap bekerja dalam organisasi tersebut. Continuance commitment merupakan komitmen yang didasarkan pada akibat yang harus dihadapi oleh karyawan bila meninggalkan organisasi. Normative commitment merupakan komitmen yang berasal dari peraturan dan kewajiban yang dirasakan oleh karyawan untuk tetap bertahan di organisasi. Setiap individu dapat memiliki salah satu dari ketiga komponen komitmen tersebut dengan derajat yang berbeda.

Pada penelitan terdahulu yang mendukung pernyataan bahwa komitmen organisasi berpengaruh terhadap kesiapan dalam menghadapi perubahan yaitu penelitian yang dilakukan oleh Madsen, Miller, dan John (2005). Hasil dari penelitian menyimpulkan bahwa komitmen organisasi berpengaruh terhadap kesiapan dalam menghadapi perubahan. Berbeda dengan penelitian yang dilakukan oleh Madsen, Miller, dan John (2005). Penelitian yang dilakukan Frans Dedi Siahaan, (2009) menyatakan bahwa tidak terdapat pengaruh yang signifikan komitmen organisasi terhadap kesiapan dalam menghadapi perubahan. Perbedaan hasil penelitian tersebut yang membuat penulis perlu melakukan penelitian.

Faktor eksternal lain yang mempengaruhi kesiapan dalam menghadapi perubahan adalah iklim psikologis. Menurut Burke, Boruski, dan Kaufman (2002) iklim psikologis merupakan persepsi individu terhadap karakteristik pekerjaan. Karakteristik berupa karakteristik peran, jenis pekerjaan, perilaku pimpinan, kelompok kerja, dan linkungan sosial individu. Martin, Jones, dan Callan (2005) menyatakan bahwa iklim psikologis berpengaruh terhadap kesiapan dalam menghadapi perubahan. Penelitian ini menunjukan bahwa karyawan yang mempersepsikan organisasi dan lingkungan kerja secara positif lebih siap dalam menjalankan perubahan.

Berdasarkan permasalahan yang telah dijabarkan, akhirnya penulis memilih untuk melakukan penelitian tentang kesiapan dalam menghadapi perubahan. Faktor-faktor yang akan digunakan sebagai prediktor dari kesiapan dalam menghadapi perubahan, antara lain: modal psikologis yang memiliki empat dimensi (self-efficacy, optimism, hope, resiliency), komitmen organisasi yang memiliki tiga dimensi (affective commitment, continuance commitment, dan normative commitment), iklim psikologis yang memiliki lima dimensi (kejelasan peran, perasaan telah memberikan kontribusi, penghargaan atas hasil kerja 
yang dicapai, kebebasan berekspresi, tantangan pekerjaan). Judul penelitian ini "Pengaruh modal psikologis, komitmen organisasi, dan iklim psikologis terhadap kesiapan dalam menghadapi perubahan".

\section{Kesiapan Dalam Menghadapi Perubahan}

Kesiapan dalam menghadapi perubahan merupakan keyakinan karyawan bahwa organisasi mampu melaksanakan perubahan yang diusulkan, perubahan yang dilakukan sesuai dengan organisasi, para pemimpin berkomitmen untuk perubahan yang diusulkan, dan perubahan yang diusulkan bermanfaat bagi anggota organisasi sebagaimana yang diungkapkan oleh Holt, Armenikes, Field \& Haris (2007).

\section{Modal Psikologis}

Modal psikologis merupakan kapasitas psikologis positif yang dimiliki oleh setiap individu yang berguna dalam membantu individu untuk dapat berkembang, yang meliputi kepercaya diri untuk menyelesaikan pekerjaan, memiliki pengharapan positif tentang keberhasilan saat ini dan dimasa yang akan datang, tekun dalam berharap untuk berhasil, dan ketahanan dalam menghadapi berbagai permasalahan dalam mencapai sukses sebagaimana diungkapkan oleh Luthans, Youssef, dan Avalio (2007).

\section{Komitmen organisasi}

Komitmen organisasi merupakan konstruk psikologis yang merupakan karakteristik hubungan anggota organisasi dengan organisasinya yang memiliki implikasi terhadap keputusan individu untuk melanjutkan keanggotaannya dalam berorganisasi, yang terdiri dari affective commitment, continuance commitment, dan normative commitmnet sebagaimana diungkapkan oleh Mayer dan Allen (1991).

\section{Iklim Psikologis}

Iklim psikologis merupakan situasi kehidupan lingkungan kerja yang dipersepsikan oleh individu, yang meliputi kejelasan peran, kontribusi, penghargaan, ekspresi diri, dan tantangan sebagaimana diungkapkan oleh Burke, Borucki, dan Kaufman (2005).

\section{METODE PENELITIAN}

Kesipan dalam mengahadapi perubahan ditentukan sebagai dependent variable pada penelitian ini. Sementara modal psikologis, komitmen organisasi, dan iklim psikologis ditetapkan sebagai independent variable. Alat pengumpul data dalam penelitian ini yaitu kuesioner berupa skala likert empat poin yang dibuat berdasarkan pengembangan teori dari masing-masing variabel yang digunakan dalam penelitian ini. Skala iyang digunakan dalam penelitian ini meliputi modifikasi Measuring Readiness for Change yang dibuat oleh Holt, Armenakis, 
Field, dan Haris (2007), modal psikologis questionare (PCQ) yang dibuat oleh Luthans, Youssef, dan Avolio (2007), measuring komitmen organisasi yang dibuat oleh Allen dan Mayer (1990), dan iklim psikologis scale yang dibuat oleh Brown dan Leigh (1996). Subjek dalam penelitian ini adalah Sampel berjumlah 162 orang. Subjek penelitian diambil menggunakan teknik accidental sampling. Metode analisis data yang digunakan dalam penelitian ini yaitu analisis regresi berganda.

\section{HASIL DAN PEMBAHASAN}

Hasil uji hipotesis analisis regresi berganda dapat dilihat pada tabel 1.

Tabel 1

Anova Pengaruh Keseluruhan Independent Variable terhadap Dependent Variable

\begin{tabular}{llllrl}
\hline & Sum of Squares & Df & Mean Square & F & Sig. \\
\hline Regression & 6366.021 & 12 & 530.502 & 9.957 & $.000^{\mathrm{a}}$ \\
Residual & 7885.565 & 149 & 53.281 & & \\
Total & 14251.586 & 161 & & &
\end{tabular}

a. Predictors: (Constant), self-efficacy, optimism, hope, resiliency, affective commitment, continuance commitment, normative commitment, kejelasan peran, kontribusi, penghargaan, tantangan, ekspresi diri.

b. Dependent variable: readiness

Berdasarkan tabel 1, diketahui bahwa nilai signifikansi uji $\mathrm{F}$ adalah 0.000 dimana taraf signifikansi $5 \%$ atau 0.05 , maka hipotesis nihil yang menyatakan bahwa tidak ada pengaruh yang signifikan dari seluruh independent variable (self efficacy, optimism, hope, resiliency, affective commitment, continuance commitment, normative commitment, dan kejelasan peran, kontribusi, penghargaan, ekspresi diri, tantangan) terhadap dependent variable (terhadap kesiapan dalam menghadapi perubahan) ditolak. Hal tersebut berarti bahwa ada pengaruh yang signifikan dari self efficacy, optimism, hope, resiliency, affective commitment, continuance commitment, normative commitment, dan kejelasan peran, kontribusi, penghargaan, ekspresi diri, tantangan terhadap terhadap kesiapan dalam menghadapi perubahan.

Tabel 2

Koefisien Regresi

\begin{tabular}{lccc}
\hline \multirow{2}{*}{ Model } & $\begin{array}{c}\text { Unstandardized } \\
\text { Coefficients }\end{array}$ & $\begin{array}{c}\text { Standardized } \\
\text { Coefficients }\end{array}$ & \multirow{2}{*}{ Sig } \\
\cline { 2 - 3 } & Beta & Beta & \\
\hline (constant) & 21.699 & & .006 \\
Selfefficacy & .289 & .283 & .001 \\
Optimism & .147 & .127 & .111 \\
Hope & -.033 & -.035 & .620 \\
Resiliency & -.072 & -.066 & .428 \\
Affective commitment & .092 & .097 & .195 \\
Continuans commitment & -.002 & -.002 & .983
\end{tabular}




\begin{tabular}{lccc} 
Normative commitment & -.135 & -.143 & .078 \\
Kejelasan peran & .173 & .154 & .069 \\
Kontribusi & -.011 & -.008 & .910 \\
Penghargaan & .200 & .156 & .031 \\
Ekspresi diri & .375 & .336 & .000 \\
Tantangan & -.057 & -.045 & .543 \\
\hline
\end{tabular}

a. Dependent Variable: readiness

Berdasarkan tabel 2, dapat diketahui persamaan regresinya sebagai berikut: Kesiapan dalam menghadapi perubahan (readiness) $=21,699+0,289$ self efficacy $^{*}+0,147$ optimism $-0,033$ hope $-0,072$ Resiliency $+0,092$ affective commitment $-0,002$ continuance commitment $-0,135$ normative commitment + 0,173 kejelasan peran $-0,011$ kontribusi $+0,200$ penghargaan $*+0,375$ ekspresi diri* $-0,057$ tantangan.

Pada tabel 2, signifikan atau tidaknya koefisien regresi yang dihasilkan dapat dilihat dari nilai sig pada kolom paling kanan. Apabila Sig $<0.05$ maka koefisien regresi yang dihasilkan signifikan pengaruhnya terhadap kesiapan dalam menghadapi perubahan. Berdasarkan data pada tabel 2, dapat disimpulkan bahwa hanya self efficacy, penghargaan, dan ekspresi diri yang memiliki pengaruh yang signifikan terhadap dependent variable (kesiapan dalam menghadapi perubahan). Adapun penjelasan mengenai nilai koefisien regresi dari masing-masing independent variable adalah sebagai berikut:

1. Variabel self efficacy memiliki nilai koefiesien regresi dengan arah positif sebesar 0,289 dan nilai signifikansi sebesar 0,001 $(\mathrm{p}<0.05)$, maka dapat disimpulkan bahwa hipotesis nihil $(\mathrm{H} 0)$ ditolak. Jadi, dapat dikatakan bahwa terdapat pengaruh yang signifikan self efficacy terhadap kesiapan dalam menghadapi perubahan (readiness). Arah koefisien positif menunjukan semakin tinggi self efficacy maka kesiapan dalam menghadapi perubahan semakin tinggi pula.

2. Variabel optimism memiliki nilai koefisien regresi sebesar 0,147 dengan signifikasin sebesar 0,111 ( $>0.05)$, maka dapat disimpulkan bahwa hipotesis nihil (H0) tidak ditolak.

3. Variabel hope memiliki nilai koefiesien regresi sebesar 0,033 dengan signifikansi sebesar 0,620 ( $p>0.05)$, maka dapat disimpulkan bahwa hipotesis nihil ( $\mathrm{H} 0)$ tidak ditolak.

4. Variabel resiliency memiliki koefisien regresi sebesar 0,072 dengan nilai signifikansi sebesar 0,428 ( $p>0.05)$, maka dapat disimpulkan bahwa hipotesis nihil $(\mathrm{H} 0)$ tidak ditolak.

5. Variabel affective commitment memiliki nilai koefiesien regresi sebesar 0,092 dengan signifikansi sebesar 0,195 ( $\mathrm{p}>0.05$ ), maka dapat disimpulkan bahwa hipotesis nihil $(\mathrm{H} 0)$ tidak ditolak.

6. Variabel continuance commitment memiliki nilai koefisien regresi sebesar 0,002 dengan signifikansi sebesar 0,983 ( $\mathrm{p}>0.05$ ), maka dapat disimpulkan bahwa hipotesis nihil (H0) tidak ditolak. 
7. Variabel normative commitment memiliki nilai koefisien regresi sebesar 0,135 dengan signifikansi sebesar 0,078 ( $p>0.05)$, maka dapat disimpulkan bahwa hipotesis nihil (H0) tidak ditolak.

8. Variabel kejelasan peran memiliki nilai koefisien regresi sebesar 0,173 dengan signifikansi sebesar 0,069 ( $\mathrm{p}>$

0.05), maka dapat disimpulkan bahwa hipotesis nihil (H0) tidak ditolak.

9. Variabel kontribusi memiliki nilai koefisien regresi sebesar 0,011 dengan signifikansi sebesar 0,910 ( $>0.05)$, maka dapat disimpulkan bahwa hipotesis nihil (H0) tidak ditolak.

10. Variabel penghargaan memiliki nilai koefisien regresi dengan arah positif sebesar 0,200 dan signifikansi sebesar 0,031 $(\mathrm{p}<0.05)$, maka dapat disimpulkan bahwa hipotesis nihil $(\mathrm{H} 0)$ ditolak. Jadi, dapat dikatakan bahwa terdapat pengaruh yang signifikan penghargaan terhadap kesiapan dalam menghadapi perubahan (readiness). Arah koefisien positif menunjukan bahwa semakin tinggi penghargaan maka kesiapan dalam menghadapi perubahan semakin tinggi pula.

11. Variabel ekspresi diri memiliki nilai koefisien regresi dengan arah positif sebesar 0,375 dan signifikansi sebesar 0,000 $(\mathrm{p}<0.05)$, maka dapat disimpulkan bahwa hipotesis nihil (H0) ditolak. Jadi, dapat dikatakan bahwa terdapat pengaruh yang signifikan ekspresi diri terhadap kesiapan dalam menghadapi perubahan (readiness). Arah koefisien positif menunjukan semakin tinggi ekspresi diri maka kesiapan dalam menghadapi perubahan semakin tinggi pula.

12. Variabel tantangan memiliki nilai koefisien regresi dengan arah positif sebesar $0,057$ dan signifikansi sebesar 0,543 ( $p>0.05)$, maka dapat disimpulkan bahwa hipotesis nihil $(\mathrm{H} 0)$ tidak ditolak.

\section{Besaran Muatan Independent Variable terhadap Dependent Variable}

Pada bahasan sebelumnya, dapat diketahui bahwa terdapat tiga independent variable yang memiliki pengaruh signfikan terhadap kesiapan dalam menghadapi perubahan, yaitu self efficacy, penghargaan, dan ekspresi diri. Peneliti juga ingin mengetahui bagaimana besaran muatan atau kontribusi dari masing-masing independent variable berpengaruh terhadap kesiapan dalam menghadapi perubahan, lalu mengurutkannya dari besaran muatan yang paling besar hingga yang paling kecil. Pada akhirnya akan diketahui prediktor mana yang memiliki pengaruh paling besar terhadap kesiapan dalam menghadapi perubahan. Berdasarkan data pada tabel 2, dapat diketahui bahwa urutan prediktor yang memiliki kontribusi terhadap kesiapan dalam menghadapi perubahan dari yang terbesar hingga yang terkecil adalah ekspresi diri dengan kontribusi 0.336, selfefficacy dengan kontribusi 0.283 , penghargaan dengan kontribusi 0.156 .

\section{DISKUSI}

Penelitian ini bertujuan untuk membuktikan variabel yang mempengaruhi kesiapan dalam menghadapi perubahan. Berdasarkan penelitian yang telah dilakukan, diketahui bahwa dari variabel psychological capital, organizational commitment, dan psychological 
climate yang diteliti terdapat tiga variabel yang mempengaruhi kesiapan dalam menghadapi perubahan secara signifikan. Ketiga variabel yang berpengaruh secara signifikan yaitu variabel psychological capital (self efficacy) dan psychological climate (penghargaan dan ekspresi diri).

Variabel self efficacy berpengaruh terhadap kesiapan dalam menghadapi perubahan secara signifikan. Hal ini sesuai dengan penelitian yang dilakukan oleh Charles, Christel, Harry, John, Bonnie, David, dan Judy (2002) yang menyatakan bahwa individu yang memiliki skor self efficacy yang tinggi dilaporkan memiliki kesiapan yang tinggi untuk perubahan. Berdasarkan hasil penelitian menunjukan bahwa 53\% sampel penelitian memiliki skor self efficacy yang tinggi. Individu yang yakin terhadap kemampuan yang dimiliki percaya akan dapat menjadi sukses saat melakukan sesuatu pekerjaan tertentu (Bandura dalam Luthans, Youssef, \& Avolio, 2007). Individu yang memiliki tingkat self efficacy yang tinggi memiliki kesiapan terhadap perubahan yang tinggi pula.

Variabel penghargaan berpengaruh terhadap kesiapan dalam menghadapi perubahan secara signifikan. Hal ini sesuai dengan penelitian yang dilakukan oleh Martin, Jones, dan Callan (2005) yang menyatakan bahwa terdapat pengaruh penghargaan terhadap kesiapan dalam menghadapi perubahan. Sesuai dengan pernyataan Brown dan Leigh (1996) yang menyatakan bahwa individu mempersepsikan bahwa tugas yang dilakukan dengan baik dihargai oleh perusahaan sehingga individu termotivasi untuk mencapai tujuan yang lebih tinggi. Individu yang mempersepsikan bahwa jika ia mampu melakukan perubahan sesuai dengan tujuan perusahaan ia akan mendapat penghargaan dari perusahaan sehingga termotivasi dan siap dalam perubahan organisasi. Namun, hasil penelitian ini tidak sejalan dengan penelitian yang dilakukan oleh Frans (2009) yang menyatakan bahwa tidak terdapat pengaruh yang signifikan penghargaan terhadap kesiapan dalam menghadapi perubahan.

Variabel ekspresi diri berpengaruh terhadap kesiapan dalam menghadapi perubahan. Hal ini sesuai dengan penelitian yang dihasilkan oleh Jelpa (2008) mengemukakan bahwa ekspresi diri di tempat kerja memiliki pengaruh yang signifikan terhadap kesiapan untuk berubah. Pernyataan tersebut didukung oleh Brown dan Leigh (1996) menyatakan bahwa individu mempersepsikan dirinya ditempat kerja. Rasa aman secara psikologis terkait dalam hal mengekspresikan diri secara utuh melalui kreativitas sehingga mampu menampilkan konsep diri yang sebenarnya. Individu tidak merasa bahwa dirinya dibatasi dalam berkreasi dan berekspresi sehingga jika perusahaan melakukan perubahan organisasi ia akan siap karena ia tetap dapat bebas berkreasi dan berekspresi. Namun, hasil penelitian ini tidak sejalan dengan penelitian yang dilakukan oleh Frans (2009) yang menyatakan tidak terdapat pengaruh yang signifikan ekspresi diri terhadap kesiapan dalam menghadapi perubahan.

Dalam penelitian ini terdapat beberapa variabel yang tidak berpengaruh secara signifikan terhadap kesiapan dalam menghadapi perubahan. Adapun 
variabel yang tidak berpengaruh secara signifikan terhadap kesiapan dalam menghadapi perubahan yaitu beberapa dimensi dari psychlogical capital antara lain optimism, hope, dan resiliency. Hal ini tidak sejalan dengan penelitian yang dilakukan oleh Jenney menyatakan bahwa optimism sangat berkorelasi terhadap kesiapan perubahan, karena orang yang pesimis hanya mengamati masalah berdasarkan hambatan sementara orang yang optimis melihat peluang dan kemungkinan untuk menyelesaikan masalah. Optimis cenderung lebih antusias dan positif terhadap perubahan. Variabel resiliency pada penenlitian ini tidak berpengaruh secara signifikan. Hal ini sejalan dengan penelitian yang dilakukan oleh Frans (2009) yang menyatakan bahwa resiliency tidak memiliki pengaruh secara signifikan terhadap kesiapan dalam menghadapi perubahan dan resiliency bukan prediktor yang baik dari kesiapan individu dalam menghaapi perubahan organisasi. Variabel hope pada penelitian ini tidak memiliki pengaruh yang signifikan terhadap kesiapan individu dalam menghadapi peruabahan organisasi. Hal ini tidak sejalan dengan penelitian yang dilakukan oleh Avey, Wersing dan Luthans (2008) yang menyatakan bahwa orang yang memiliki hope yang tinggi maka akan termotivasi untuk melakukan perubahan yang lenbih baik. Namun, menurut Holt et. all. (2007) apabila terdapat gap antara harapan organisasi dan anggota organisasi maka resistensi terhadap perubahan akan muncul dan mengancam implementasi program perubahan. Jika harapan organisasi dan anggota organisasi sejalan maka hope dapat menjadi motivasi positif yang didasari oleh interaksi perasaan sukses meliputi Agency dan Pathways. Agency yaitu tekad untuk mencapai tujuan. Pathways yaitu perencanaan untuk mencapai tujuan. Dari definisi ini, dimensi hope melibatkan willpower dan waypower. Willpower merupakan suatu dimensi penting karena dapat memicu motivasi dan menjaga energi seseorang untuk mencapai tujuannya. Waypower merupakan rencana alternative hasil pemikiran seseorang untuk mencapai tujuannya.

Selain variabel psychological capital, terdapat variabel organizational commitment yang juga tidak berpengaruh secara signifikan terhadap kesiapan individu dalam menghadapi peruabahan organisasi. Hal ini sejalan dengan penelitian yang dilakukan oleh Frans (2009) yang menyatakan bahwa komitmen organisasi tidak berpengaruh secara signifikan terhadap kesiapan individu menghadapi peruabahn organisasi. Namun, hasil penelitian ini tidak sejalan dengan penelitian yang dilakukan oleh Madsen, miller, dan john (2005) yang menyatakan bahwa komitmen individu terhadap organisasi berpengaruh terhadap kesiapan dalam menghadapi perubahan. Continuance commitment tidak berpengaruh terhadap kesiapan untuk berubah ini ini didukung dengan pernyataan Mayer dan Allen (1990) yang menyatakan bahwa Continuance commitment adalah komponen komitmen yang berbeda dengan kedua komitmen yang lainnya, continuance commitment hanya berkorelasi dengan 
beberapa variabel, selebihnya tidak akan ditemukan korelasi. Vakola dan Nikolau (2005) juga menyatakan bahwa komitmen organisasi akan menentang perubahan organisasi jika karyawan hanya memikirkan keuntungan yang diperolehnya dalam organisasi, sehingga karyawan tersebut tidak peduli dengan organisasinya, mereka hanya mengestimasi untung dan rugi dalam keanggotaanya dalam organisasi.

Variabel lain yang tidak berpengaruh terhadap kesiapan dalam menghadapi perubahan yaitu beberapa dimensi dari psychological climate antara lain kejelasan peran, kontribusi, dan tatangan. Hal ini tidak sejalan dengan penelitian yang dilakukan oleh Frans (2009) yang menyatakan bahwa kejelasan peran dan kontibusi memiliki pengaruh positif dan signifikan terhadap kesiapan individu dalam menghadapi peruabahan organisasi.

Penulis berasumsi bahwa hasil penelitian yang tidak signifikan pada beberapa variabel tersebut berasal dari kekurangan dan kelemahan peneliti sendiri, seperti kurang tepatnya bahasa yang digunakan dalam adaptasi item serta pemilihan skala atau alat ukur dalam mengukur variabel. Selain itu peneliti juga berasumsi bahwa tidak signifikannya pengaruh beberapa independent variable berasal dari subjek penelitian saat mengisi kuesioner penelitian, seperti adanya faking good terhadap item karena kecenderungan subjek untuk mengisi sesuai dengan norma yang berlaku, suasana hati, serta saat pengambilan data penulis tidak dapat melihat secara langsung bagaimana berlangsungnya pengambilan data sehingga penulis tidak dapat mengobservasi dan melihat bagaimana responden mengisi kuisioner dan banyak hasil kuesioner yang sama dengan responden lain. Pada penelitian selanjutkan sebaiknya peneliti dapat mengambil data langsung bertemu dengan responden.

\section{KESIMPULAN DAN SARAN}

Berdasarkan hasil analisa data dan pengujian, maka dapat diambil beberapa kesimpulan dari penelitian ini, yaitu:

1. Ada pengaruh yang signifikan secara bersama-sama dari psychological capital (self efficacy, optimism, hope, resiliency), organizational commitment (affective commitment, continuance commitment, normative commitment) kejelasan peran, kontribusi, penghargaan, ekspresi diri, tantangan, dan psychological climate (kejelasan peran, kontribusi, penghargaan, ekspresi diri, tantangan) terhadap kesiapan dalam menghadapi perubahan

2. Ada tiga variabel yang memiliki pengaruh yang signifikan terhadap kesiapan dalam menghadapi perubahan, yaitu self-efficacy, ekspresi diri, dan penghargaan. Salah satu variabel yang memiliki pengaruh paling besar terhadap kesiapan dalam menghadapi perubahan dalam penelitian ini adalah penghargaan.

Berdasarkan hasil penelitian, peneliti menyadari bahwa masih terdapat banyak kekurangan dan keterbatasan dalam penelitian ini di dalamnya. Untuk itu, peneliti memberikan beberapa saran yang dapat dijadikan bahan evaluasi dan penyempurnaan bagi penelitian di masa mendatang. 
1. Berdasarkan hasil penelitian pengaruh psychological capital, organizational commitment, dan psychological climate terhadap kesiapan dalam menghadapi perubahan sebesar $44,7 \%$, sedangkan $55,3 \%$ dipengaruhi oleh variabel lain. Untuk penelitian selanjutnya disarankan untuk melibatkan variabel lain seperti discrepancy dan tuntutan dari organisasi untuk berubah karena variabel tersebut termasuk salah satu faktor yang mempengaruhi kesiapan dalam menghadapi perubahan.

2. Pada penelitian ini penulis hanya menggunakan metode kuantitatif sehingga penulis memiliki keterbatasan dalam menganalisa hasil. Untuk penelitian selanjutnya disarankan selain menggunakan metode kuantitatif juga menggunakan metode lain seperti observasi dan dan wawancara agar dapat mengetahui makna dependent variable secara lebih mendalam.

3. Pada penelitian ini penulis menggunakan skala adaptasi dari penelitian sebelumnya yang berbahasa inggris. Seluruh item dari skala yang digunakan berjumlah 102 item sehingga banyak sampel yang mengeluh terlalu banyak itemnya. Pada penelitian selanjutnya disarankan agar tidak terlalu banyak

4. Berdasarkan hasil penelitian self-efficacy memiliki kontribusi yang besar terhadap kesiapan dalam menghadapi perubahan. Perusahaan perlu meningkatkan selfefficacy karyawannya. Cara meningkatkan self- efficacy karyawan dengan memberikan training terhadap karyawan, berupa team building baik dalam ruangan dan di luar ruangan seperti outbond, selain itu perusahaan juga dapat mendatangkan motivator.

5. Berdasarkan hasil penelitian penghargaan juga memiliki pengaruh yang signifikan terhadap kesiapan dalam menghadapi perubahan. Perusahaan perlu menghargai pekerjaan karyawan dengan cara memberikan reward jika karyawan berhasil memenuhi target dan memberikan promosi jabatan bagi karyawan yang berkompeten dalam pekerjaannya.

6. Berdasarkan hasil penelitian ekspresi diri memiliki pengaruh yang signifikan terhadap kesiapan dalam menghadapi perubahan. Perusahaan perlu menciptakan lingkungan yang demokratis seperti dalam rapat pemimpin memberikan kesempatan kepada karyawan untuk berpendapat dan mengeluarkan ide-ide yang dimiliki. 


\section{REFERENSI}

Allen, N. J., Mayer, J. P. (1990). The measurement and antecedents of affective, continuance and normative commitment to the organization. Journal of Occupational Psychology Society.63, 1-18.

Avey, J., Wernsing, T. S., Luthans, F. (2008). Can positive employees help positive organizational change? Impact of psychological capital and emotions on relevant attitudes and behaviors. The Journal of Applied Behavioral Science. 44 (1), 48-70.

Bovey, W. H., Hede, A. (2001). Resistance to organizational change: the role of cognitive and affective processes. Leadership \& Organizational Development Journal. 22(8), 372-382.

Brown, P.W., Leigh, T. W. A. (1996). New look at psychological climate and its relatioship to job involvement, effort, and performance. Journal of Applied Psychology. 81 (4), 358-368.

Burke, M. J., Borucki, C. C., Kaufman J. D. (2002). Contemporary perspectives on the study of psychological climate: A commentary. European Journal of Work and Organizational Psychology. 11(3), 325-340.

Coetzee, S. E., Rotmann, S. (2005). Occupational stress, organitational commitment and ill-health of employees at a higher education institution in South Africa. Journal of Industrial Psychology. 31 (1), 47-54. Davidson, J. (2005). The complete ideal's guide: change management. Jakarta: Prenada.

Hardian, E. (2015). Ini penyebab disc tarra bisa tutup. Diunduh pada tanggal 20 April 2016 dari http://celebrity.okezone.com/read/2015/11/04/205/ 1243433/inipenyebab-disc-tarra-bisa-tutup

Holt, D. T., Armenakis, A. A., Feild, H. S., Harris, S. G. (1993). Creating readiness for organizational change. Journal of Applied Behavioral Science. 43 (2), 232-255.

Jelpa, P. (2008). Pengaruh keadilan organisasi, komitmen organisasi, dan iklim organisasi terhadap kesiapan terhadap perubahan Organisasi. Skripsi. Depok: Universitas Indonesia.

Latif, M. O., Krisbianto, N. (2008). Spesial report trend HR 2008. Jakarta: Human Capital Magazine.

Luthans, F., Youssef, C. M., Sweetman, D. S., Harms, P. D. (2013). Meeting the leadership challenge of employee well-being through relationship psycap and health psycap. Management department. 20 (1), 118-133.

Luthans, F., Youssef, C. M., Avolio, B. J. (2007). Psychological capital developing the human competitive edge. New York: Oxford University press.

Madsen, S. R., Miller, D., John, C. R. (2005). Readiness for organizational change: do organizational commitment and social relationship in the workplace make a difference. Human Resource Development Quarterly. 16 (2), 213-233.

Mertin, A. J., Jones, E. S., Callan, V. J. (2005). The role of psychological climate ini facilitating employee adjustment during orgnizational change. Europa Journal of Work and Organizational Psychology. 14 (3), 263-289. 
Partigrew, A. M. (1987). Context and action in the transformation of the firm. Journal of Management Studies. 24 (6), 649-670.

Porter, L. W., Steers, R. M., Mowday, R. T., Boulian, P. V. (1974). Organizational commitment, job satisfaction, and turnover among psychiatric technicians. Journal of Applied Psychology. 59(5), 603-609.

Panggabean, M. (2004). Manajemen Sumber Daya Manusia. Cetakan Kedua. Bogor: Ghalia Indonesia.

Rafferty, A. E., Simons, R. H. (2006). An examination of the antecedents of readiness for fine-tuning and corporate transformation changes. Journal of Business dan Psychology. 20 (3), 325-250.

Seniati, A. (2002). Pengaruh masa kerja, trait kepribadian, kepuasan kerja, dan iklim psikologis terhadap komitmen dosen pada universitas Indonesia. Disertasi Psikologi Industri dan Organisasi Fakultas Psikologi. Depok: Universitas Indonesia.

Siahaan, F. D. (2009). Pengaruh resiliensi, trait kepribadian, neuroticism, komitmen organisasi, dan iklim psikologis terhadap kesiapan individu dalam menghadapi perubahan organisasi. Skripsi. Depok: Universitas Indonesia. Swift, C., Campbell, C. (1998).

Psychological climate: relevance for sales managers and impact on cinsequent job satisfaction. Journal of Marketing Theory and Practice.

Umar, J. (2012). "Statistika mentor akademik." Bahan Ajar Fakultas Psikologi UIN Jakarta. Tidak Dipublikasikan.

Vakola, M., Nikolaou, L. (2005). Attitudes towards organizational change what is the role of employees' stress and commitment? Journal Employee Relations. 27 (2), 160174.

Vermeulen, F., Puranam, P., Gulati, R. (2010). Change for change's sake. London: Harvard Business School Publication Coproration.

Wirawan. (2007). Budaya dan Iklim Organisasi. Jakarta: Salemba Empat.

Yuwono, C. D. I., Putra, M. G. B. A. (2005). Faktor emosi dalam proses perubahan organisasi. Jurnal psikologi. 7(3), 250-263. 